\title{
Geografická reprezentativita poslancov NR SR zvolených v podmienkach jedného volebného obvodu
}

\author{
Tibor Madleňák ${ }^{1}$ \\ Katedra geografie a geológie, Fakulta prírodných vied UMB, Banská Bystrica \\ The Geographical Representativeness of the Deputies Elected to the National Council \\ of the Slovak Republic in Terms of Single Electoral District. The article identifies and \\ analyzes the patterns of political representation of the regions of Slovakia in terms of the \\ functioning of the proportional electoral system with only one electoral district for the whole \\ country. In this system, the representation of the region of the capital city, which is several \\ times higher than the representation of other regions, dominates significantly. At the same \\ time, a Western-Eastern gradient was identified in the regional political representation \\ pattern, where the more economically developed western part of the country is politically \\ much better represented than the peripheral regions of eastern Slovakia. The impact of a \\ single electoral district is relevant in the geographical context as well as in significant \\ centralization of the political power within the party-political system. \\ Sociológia 2019, Vol. 51 (No. 5: 483-501) \\ https://doi.org/10.31577/sociologia.2019.51.5.22
}

Key words: Political representation; regions; electoral system; electoral district; parliament; Slovakia

\section{Úvod}

V zastupitel'skej demokracii sa občania podiel'ajú na politickej moci prostredníctvom volených zástupcov, ktorí ich reprezentujú. Miera a charakter politickej reprezentácie občanov závisí vo vel'kej miere od volebného systému, ktorý predstavuje základný rámec pre fungovanie stranícko-politického systému v demokratických štátoch. Nastavenie volebných pravidiel pre jednotlivé typy volieb je preto vel'mi citlivá záležitost', o ktorej sa diskutuje nielen medzi politikmi, ale aj odbornou i laickou verejnost'ou.

Pre vol'by do Národnej rady Slovenskej republiky (NR SR), ktoré sú vzhl'adom na nastavenie politického systému na Slovensku považované za najdôležitejšie, platí pomerný volebný systém. Vd'aka nemu majú v NR SR zastúpenie politické strany a hnutia, ktoré získajú zákonom stanovené kvórum platných voličských hlasov ${ }^{2}$. Takto nastavený volebný systém umožňuje politické zastúpenie širšiemu spektru politických strán, ktoré sa na Slovensku vyvinuli v súvislosti s pôsobením viacerých konfliktných línií (Strmiska et al. 2005; Madleňák 2012). Pomerný volebný systém má na Slovensku aj svoju historickú tradíciu z čias medzivojnového Československa (Zemko 2008). Čo však až takú historickú tradíciu nemá, a čím predstavuje súčasné Slovensko

\footnotetext{
${ }^{1}$ Korešpondencia: RNDr. Tibor Madleňák, PhD., Katedra geografie a geológie, Fakulta prírodných vied, Univerzita Mateja Bela, Tajovského 40, 97401 Banská Bystrica, Slovensko. E-mail: tibor.madlenak@umb.sk

$25 \%$ v prípade jednej politickej strany, $7 \%$ pre koalície dvoch alebo troch strán, $10 \%$ pre koalície štyroch a viac strán.
} 
vel’mi špecifický prípad aj v širšom regióne, je existencia jedného volebného obvodu, ktorý od roku 1998 nahradil dovtedy existujúce 4 volebné obvody. Stalo sa tak značne účelovou novelou volebného zákona (Zákon NR SR č. 187/1998 Z. z.) pred parlamentnými vol'bami 1998. Hoci viaceré kontroverzné ustanovenia tohto volebného zákona boli medzitým zrušené, princíp celej krajiny ako jedného volebného obvodu ostal dodnes zachovaný a patrí medzi najdiskutovanejšie otázky v rámci diskurzu o efektívnom nastavení volebného systému (napr. Spáč - Sloboda 2014; Kerekeš et al. 2019).

Ciel'om článku je identifikovat' a analyzovat' vzorce geografickej reprezentativity zloženia NR SR v podmienkach existencie jedného volebného obvodu (1998 - 2016). Vd’aka nemu predstavuje Slovensko vel'mi zaujímavý prípad z hl'adiska výskumu politickej reprezentácie regiónov, čo patrí $\mathrm{k}$ hlavným oblastiam záujmu politickej, resp. volebnej geografie (Flint - Taylor 2007, Madleňák 2010). Napriek tomuto potenciálu je téme geografickej reprezentácie na Slovensku venovaná len marginálna pozornost' (Madleňák 2017). V teoretickej rovine môže byt' zaujímavá komparácia výsledkov zo Slovenska s Holandskom a Izraelom, ktoré majú podobne nastavený volebný systém (jeden volebný obvod), pričom ich Latner a McGann (2005) označili za dva „,najextrémnejšie prípady geografickej reprezentácie“ $\mathrm{v}$ rámci pomerného volebného systému. V praktickej rovine môžu byt' analýzy vzorcov politickej reprezentácie regiónov príspevkom do aktuálnej diskusie o fungovaní volebného a v širšom zmysle aj stranícko-politického systému na Slovensku.

\section{Politická reprezentácia a geografická reprezentativita}

Otázky politickej reprezentácie sú v politológii a sociológii pomerne široko diskutované. H. Pitkin (1972) rozlišuje štyri základné typy politickej reprezentácie: formálnu, symbolickú, deskriptívnu a substantívnu reprezentáciu. Koncept geografickej reprezentácie, ktorému je venovaný tento článok, je možné zaradit' $\mathrm{k}$ deskriptívnej reprezentácii. Znamená to, že zastupitel' je svojou osobou a životnými skúsenost’ami v určitom zmysle typickým predstavitel’om skupiny l'udí, ktorú reprezentuje (Mikešová - Kostelecký 2016).

Princíp geografickej reprezentácie vychádza z kontextuálneho chápania miesta, resp. regiónu ako istého prostredia, ktoré sa vyznačuje určitými sociálnymi interakciami, spôsobom života, historickou pamätou, špecifickou politickou kultúrou a identitou, ako aj špecifickými ekonomickými záujmami (Bernard - Kostelecký 2014; Agnew 2016). Politický reprezentant tak do istej miery zdiel'a so svojimi voličmi pohl'ad na určité problémy vychádzajúci z kontextu prostredia (miesta, regiónu), z ktorého pochádza. Význam geografickej reprezentácie teda spočíva na väzbách politikov $\mathrm{k}$ určitému prostrediu a na bližšom vzt’ahu medzi voličom a kandidátom, ktorý je založený na geografickej blízkosti (Gimpel et al. 2011). Hoci v súvislosti s procesmi 
globalizácie a rozširovaním možností komunikácie, získavania a zdielania informácií, napríklad cez médiá a sociálne siete, môžu byt' vplyvy miestnych, resp. regionálnych kontextov znižované (Lee 2007), ostáva špecifické sociokultúrne a politické prostredie regiónu, v ktorom volič, ako aj jeho politický reprezentant žije, dôležitým faktorom formujúcim spôsoby jeho uvažovania a konania (Krivý et al. 1996).

Reprezentativitu je podl'a Nováka (1997) možné charakterizovat' ako indikátor toho, nakol'ko je vo volenom orgáne zastúpenie poslancov podl'a rôznych hl'adísk reprezentatívne. Geografická reprezentativita ukazuje, nakol'ko je medzi zvolenými poslancami uplatnený princíp geografickej reprezentácie, teda miera zastúpenia jednotlivých regiónov. Praktickým uplatnením konceptu geografickej reprezentácie v rámci volebného systému sú volebné obvody, ktoré sa vyskytujú v rámci väčšinových, ale aj pomerných volebných systémov. Koncept viacerých volebných obvodov sa na Slovensku využíva $\mathrm{v}$ prípade komunálnych či regionálnych volieb ${ }^{3}$. V prípade parlamentných volieb však explicitné uplatnenie princípu geografickej reprezentácie vo volebnom systéme absentuje. Poslanci tak oficiálne nereprezentujú región, z ktorého pochádzajú, ale občanov celej krajiny. V extrémnom prípade tak môžu všetci poslanci NR SR pochádzat' z jedného regiónu, mesta alebo dediny.

\section{Metodika}

Analýza vzorcov politickej reprezentácie regiónov je založená na výsledkoch všetkých parlamentných volieb na Slovensku konaných po zmene volebného systému v roku 1998 (1998, 2002, 2006, 2010, 2012 a 2016). Pri určení regionálnej príslušnosti je určujúce miesto trvalého bydliska poslanca. Analýza zahín̆a len poslancov zvolených priamo vo vol'bách. Nezohl'adňuje tak zmeny v zložení NR SR v priebehu volebného obdobia, kedy dochádza napr. $\mathrm{k}$ nástupu náhradníkov za členov vlády.

$\mathrm{V}$ analýze vystupujú regióny na úrovni okresov aj krajov. $\mathrm{V}$ prípade okresov predstavujú výnimku mestá Bratislava a Košice, ktoré nie sú členené na okresy $^{4}$. Na nižšej regionálnej úrovni je teda analyzovaných 72 a na vyššej úrovni 8 regionálnych jednotiek. Pre každý región na oboch úrovniach je $\mathrm{v}$ rámci jednotlivých volieb vypočítaný tzv. index politickej reprezentácie regiónu $\left(\mathrm{I}_{\mathrm{RRi}}\right)$, ktorý predstavuje podiel všetkých zvolených poslancov $\left(\mathrm{P}_{\mathrm{p}}\right)$

\footnotetext{
${ }^{3}$ V prípade volieb do zastupitel'stiev VÚC sú jednotlivé kraje rozdelené na viaceré volebné obvody, ktoré sa s výnimkou Bratislavského samosprávneho kraja zhodujú s okresmi. Každý volebný obvod má stanovený počet poslancov vzhl’adom na svoju vel'kost'. V prípade komunálnych volieb stanovuje zákon možnost' resp. povinnost' rozdelit' obce vzhl'adom na počet obyvatel'ov na volebné obvody s istým počtom mandátov.

4 Pre zaradenie poslancov k niektorému z bratislavských či košických okresov by bola potrebná presná adresa jeho bydliska (vrátane ulice), databáza NR SR však obsahuje len názov obce, teda Bratislavu, resp. Košice.
} 
k počtu oprávnených voličov $\left(\mathrm{P}_{\mathrm{OV}}\right) \mathrm{z}$ daného regiónu $\left(\mathrm{R}_{\mathrm{i}}\right)$. Pre väčšiu prehl'adnost' je tento podiel vynásobený konštantou 100 000:

$$
I_{R R_{i}}=\frac{\sum_{p \in R_{i}} P_{p}}{P_{O V}} .100000
$$

Výsledný index tak predstavuje počet zvolených poslancov na 100000 oprávnených voličov. Takto je možné vzájomne porovnávat' výšku politickej reprezentácie rôznych regiónov bez ohl'adu na ich vel'kost', resp. počet obyvatel'ov, čím sa eliminuje problém značných disproporcií vo vymedzení okresov a krajov na Slovensku.

Kým v predchádzajúcej analýze nie je zohl'adnená politická príslušnost' poslancov, v druhej časti štúdie je osobitne analyzovaná geografická reprezentativita parlamentného zastúpenia jednotlivých politických strán. Za relevantné sú považované všetky politické strany, ktorým sa v období 1998 - 2016 podarilo dostat' do NR SR. Celkovo ide o 17 parlamentných politických strán a hnutí. Pre každú z nich je vypočítaná tzv. miera geografickej proporcionality jej poslancov podla metódy Latner - McGann (2005). Ide o podiel relatívneho počtu poslancov $\mathrm{s}$ bydliskom $\mathrm{v}$ danom regióne a relatívneho počtu oprávnených voličov v tomto regióne ${ }^{5}$. Kým hodnota indexu nižšia ako 1 predstavuje podpriemernú, hodnota vyššia ako 1 znamená naopak nadpriemernú politickú reprezentáciu regiónu ${ }^{6}$. Tento index je síce komplikovanejší ako index politickej reprezentácie regiónov použitý v prvej časti článku, ale umožňuje navzájom porovnávat' geografickú reprezentativitu politických strán so značne rozdielnym počtom poslancov (napr. stranu SDL s 23 poslancami so stranou Smer-SD s 269 poslancami za celé skúmané obdobie) ${ }^{7}$.

$\mathrm{V}$ prípade geografickej reprezentativity na úrovni politických strán sú pre analýzu vhodnejšie kraje, ked'že $\mathrm{v}$ prípade väčšiny strán bol počet poslancov menší, čo by na úrovni 72 okresov znamenalo značné skreslenie. Aj v prípade 8 krajov má vzorec založený na regionálnej distribúcii 98 poslancov troška vyššiu výpovednú hodnotu ako vzorec distribuujúci len 11 poslancov. Počet poslancov však nikdy nebol nižší ako počet krajov, takže teoreticky aj pri strane s 10 poslancami bolo teoreticky možné dosiahnut' relatívne rovnomerné zastúpenie všetkých krajov.

Vel’a poslancov bolo v skúmaných vol'bách zvolených opakovane, sú teda do analýzy zaradení viackrát, čo je však vzhl’adom na ciele a metodiku článku

\footnotetext{
5 Miera geografickej proporcionality = (počet poslancov s trvalým bydliskom v regióne/počet poslancov NR SR)/(počet oprávnených voličov v regióne/počet oprávnených voličov SR).

${ }^{6}$ Hodnota indexu 1 znamená priemernú politickú reprezentáciu a pri každej politickej strane sa fakticky vztahuje k celej krajine.

${ }^{7}$ V prvej časti pozostával základný súbor vždy zo 150 poslancov NR SR, vzorce geografickej reprezentativity pre jednotlivé vol'by je tak možné bez problémov porovnávat'.
} 
$\mathrm{v}$ poriadku, ked’že región, $\mathrm{v}$ ktorom majú trvalý pobyt, je prostredníctvom nich (nepriamo, resp. neoficiálne) politicky reprezentovaný opakovane.

\section{Geografická reprezentativita poslancov NR SR v rokoch 1998 - 2016}

Politickú reprezentáciu regiónov v NR SR na úrovni krajov zobrazujú tabul'ky č. 1 a 2, v grafickom vyjadrení obrázok č. 1. Absolútnym ako aj relatívnym počtom poslancov stabilne vysoko dominuje Bratislavský kraj. Najvýraznejšie to bolo vo vol'bách 1998, kedy takmer polovica poslancov parlamentu (73) pochádzala $z$ tohto kraja, čo predstavuje takmer 15 poslancov na 100000 oprávnených voličov, zatial čo $\mathrm{v}$ prípade počtom obyvatel'ov najväčšieho Prešovského kraja to bolo len 7 poslancov $(1,28$ poslanca na 100000 oprávnených voličov). Ide o dve extrémne hodnoty v miere politickej reprezentácie regiónov namerané za celé sledované obdobie, kedy mali obyvatelia Bratislavského kraja takmer 12-násobne vyššiu politickú reprezentáciu než obyvatelia Prešovského kraja. Zatial' čo dominancia Bratislavského kraja ostávala napriek miernemu poklesu indexu politickej reprezentácie stabilná (najnižšia hodnota 9,58 v roku 2006), v pozícii kraja s najnižším indexom politickej reprezentácie sa okrem Prešovského (1998, 2006 a 2016) ocitli aj Žilinský (2002), Trenčiansky (2010) a Nitriansky kraj (2012). V priemere však bolo v celom sledovanom období najmenej reprezentované východné Slovensko (Prešovský a Košický kraj). Nad celoštátny priemer politickej reprezentácie sa okrem Bratislavského kraja podarilo dostat' len Trnavskému kraju, aj to len vel'mi tesne a len v dvoch vol'bách (2010 a 2012).

Tabul'ka č. 1: Počet poslancov NR SR pochádzajúcich z jednotlivých krajov $(1998-2016)$

\begin{tabular}{lccccccc}
\hline Kraj & $\mathbf{1 9 9 8}$ & $\mathbf{2 0 0 2}$ & $\mathbf{2 0 0 6}$ & $\mathbf{2 0 1 0}$ & $\mathbf{2 0 1 2}$ & $\mathbf{2 0 1 6}$ & Spolu \\
\hline Bratislavský & 73 & 59 & 50 & 63 & 59 & 67 & 371 \\
Trnavský & 11 & 14 & 13 & 16 & 16 & 13 & 83 \\
Trenčiansky & 13 & 12 & 12 & 9 & 10 & 9 & 65 \\
Nitriansky & 10 & 15 & 20 & 11 & 11 & 12 & 79 \\
Žilinský & 13 & 8 & 16 & 13 & 11 & 13 & 74 \\
Banskobystrický & 11 & 17 & 12 & 12 & 14 & 16 & 82 \\
Prešovský & 7 & 11 & 12 & 13 & 17 & 8 & 68 \\
Košický & 12 & 14 & 15 & 13 & 12 & 12 & 78 \\
Spolu & 150 & 150 & 150 & 150 & 150 & 150 & 900 \\
\hline
\end{tabular}

Zdroj: NR SR, vlastné prepočty 
Tabul'ka č. 2: Index politickej reprezentácie regiónov Slovenska na úrovni krajov (1998 - 2016)

\begin{tabular}{lccccccc}
\hline Kraj & $\mathbf{1 9 9 8}$ & $\mathbf{2 0 0 2}$ & $\mathbf{2 0 0 6}$ & $\mathbf{2 0 1 0}$ & $\mathbf{2 0 1 2}$ & $\mathbf{2 0 1 6}$ & Priemer \\
\hline Bratislavský & $\mathbf{1 4 , 9 3}$ & $\mathbf{1 1 , 6 4}$ & $\mathbf{9 , 5 8}$ & $\mathbf{1 1 , 6 9}$ & $\mathbf{1 0 , 7 3}$ & $\mathbf{1 1 , 8 8}$ & $\mathbf{1 1 , 7 4}$ \\
Trnavský & 2,65 & 3,25 & 2,91 & $\mathbf{3 , 4 8}$ & $\mathbf{3 , 4 7}$ & 2,80 & 3,09 \\
Trenčiansky & 2,85 & 2,55 & 2,48 & 1,83 & 2,03 & 1,85 & 2,27 \\
Nitriansky & 1,83 & 2,68 & 3,50 & 1,90 & 1,91 & 2,10 & 2,32 \\
Žilinský & 2,58 & 1,53 & 2,98 & 2,36 & 1,98 & 2,31 & 2,29 \\
Banskobystrický & 2,19 & 3,31 & 2,30 & 2,28 & 2,66 & 3,07 & 2,63 \\
Prešovský & 1,28 & 1,92 & 2,03 & 2,14 & 2,76 & 1,28 & 1,90 \\
Košický & 2,13 & 2,41 & 2,51 & 2,13 & 1,95 & 1,91 & 2,17 \\
Priemer & $\mathbf{3 , 7 3}$ & $\mathbf{3 , 6 1}$ & $\mathbf{3 , 5 1}$ & $\mathbf{3 , 4 4}$ & $\mathbf{3 , 4 1}$ & $\mathbf{3 , 3 9}$ & $\mathbf{3 , 5 5}$ \\
Rozptyl & 20,44 & 10,76 & 6,17 & 11,28 & 8,98 & 12,05 & 11,07 \\
Rozptyl bez BA & 0,29 & 0,42 & 0,24 & 0,31 & 0,35 & 0,36 & 0,15 \\
\hline
\end{tabular}

Zdroj: NR SR, vlastné prepočty

Obrázok č. 1: Priemerná politická reprezentácia regiónov Slovenska na úrovni krajov (1998 - 2016)

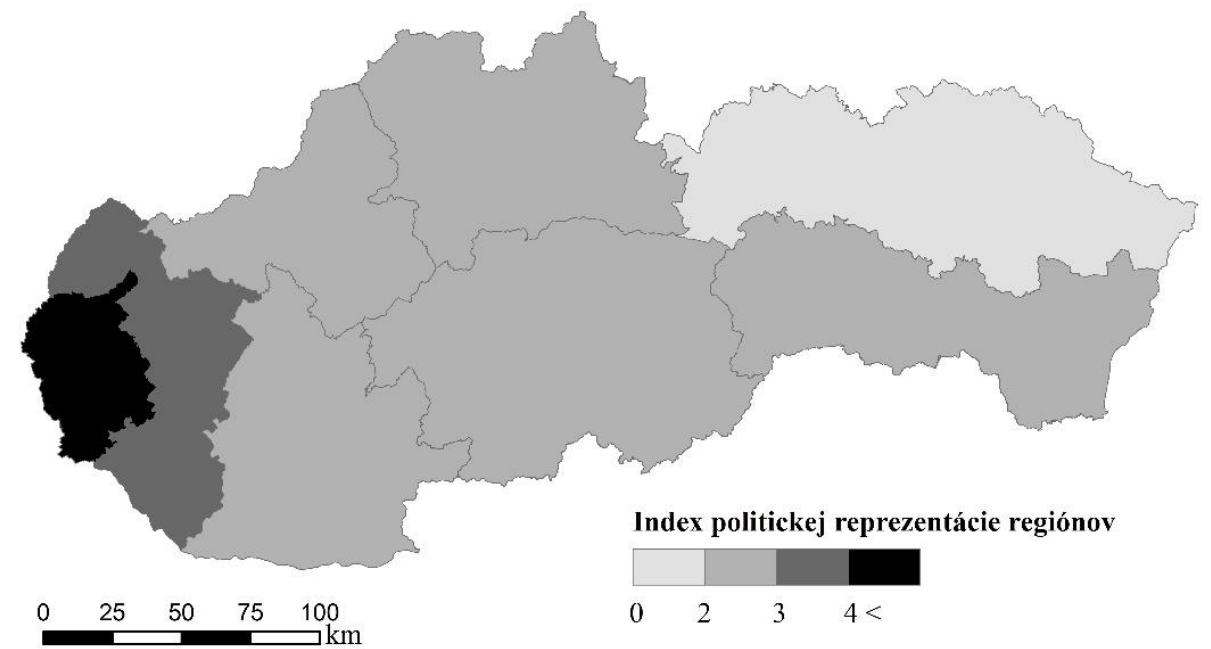

Zdroj: NR SR, spracoval autor

Vzorec geografickej reprezentativity NR SR v jednotlivých obdobiach vel'mi dobre charakterizuje aj údaj o rozptyle (tab. č. 2). Najväčšie disproporcie z regionálnom rozmiestnení poslancov sú v prípade volieb $\mathrm{v}$ roku 1998, naopak najnižšie vo vol'bách 2006. Rozptyl, teda disproporcie v analyzovaných vzorcoch sú vel'mi silne závislé od hodnoty indexu za Bratislavský kraj, ktorý vo vzorci geografickej reprezentácie vel’mi výrazne dominuje (obr. č. 1). 
V prípade zvyšných siedmych krajov (bez Bratislavského) sú regionálne disproporcie minimálne, rozdiel medzi Trnavským krajom na strane jednej a Prešovským a Košickým krajom však naznačuje mierny západo-východný gradient v politickej reprezentácii regiónov Slovenska.

Vzorce politickej reprezentácie regiónov na úrovni okresov znázorňuje séria máp na obrázku č. 2. Okresy sú diferencované vo vztahu k priemernému indexu politickej reprezentácie v jednotlivých vol'bách. Analýza na úrovni okresov umožňuje identifikovat' diferenciáciu politickej reprezentácie vo vnútri krajov. Napriek menším rozdielom je možné v prípade šiestich sledovaných volieb pozorovat' určitú stabilitu a identifikovat' isté spoločné črty vzorcov geografickej reprezentácie aj na úrovni okresov. Tie naznačuje aj syntetická mapa na obr. č. 3, ktorá znázorňuje priemernú mieru politickej reprezentácie okresov za celé sledované obdobie.

Obrázok č. 2: Vzorce politickej reprezentácie regiónov na úrovni okresov $(1998-2016)$
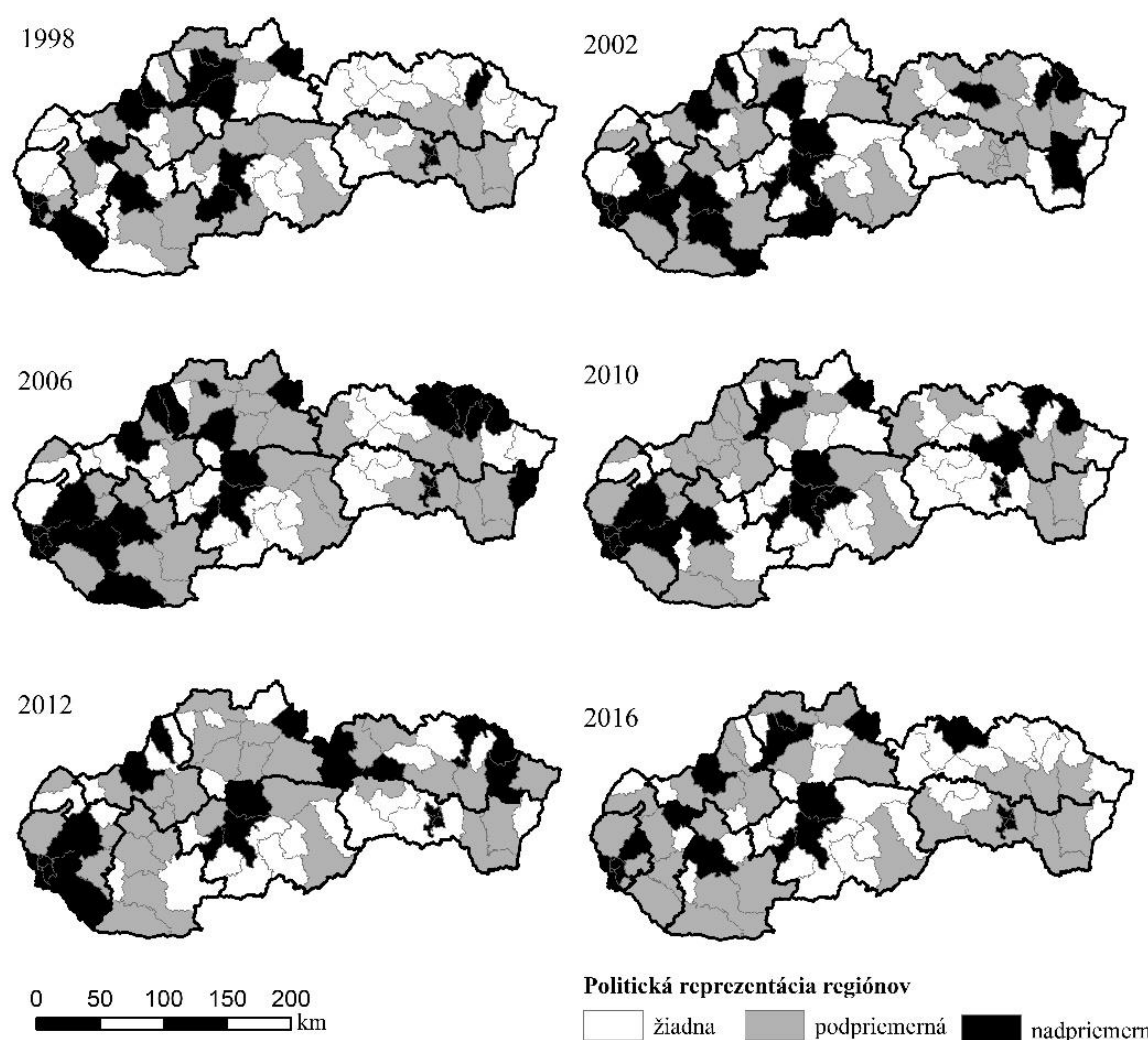

Politická reprezentácia regiónov

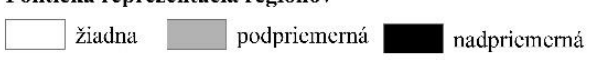

Zdroj: NR SR, spracoval autor

Sociológia 51, 2019, с̌. 5 
Kým Bratislava jednoznačne dominuje aj na tejto úrovni, v rámci Bratislavského kraja je možné pozorovat' postupné posilňovanie okresov v jej zázemí (Senec, Pezinok, Malacky) na úkor samotnej Bratislavy. Zatial' čo vo vol'bách 1998 bol z týchto troch okresov len 1 zo 73 poslancov kraja, vo vol'bách 2010, resp. 2012 tvorili približne šestinu poslancov z Bratislavského kraja. Túto skutočnost' je možné vysvetlit' procesom suburbanizácie, kedy sa čast' obyvatel'ov Bratislavy, vrátane politikov, st’ahuje do jej zázemia. Za zázemie Bratislavy je v istom zmysle možné považovat' aj okres Dunajská Streda, jej stabilne nadpriemerná politická reprezentácia je však spôsobená takmer výlučne zástupcami strán SMK a Most-Híd, teda skôr etnickým faktorom ako faktorom suburbanizácie.

\section{Obrázok č. 3: Politická reprezentácia regiónov Slovenska na úrovni okresov $(1998$ - 2016)}

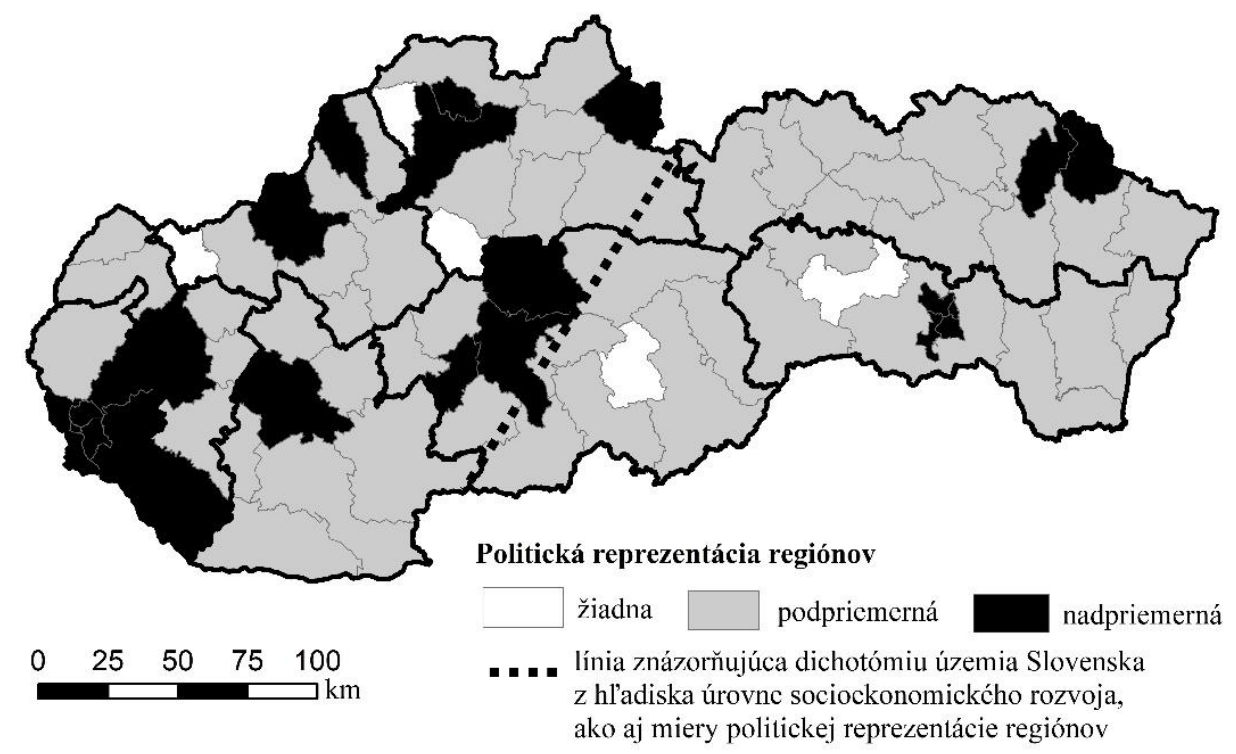

Zdroj: NR SR, spracoval autor

V rámci ostatných krajov je možné identifikovat' predovšetkým dominanciu krajských centier, ktoré sa vo väčšine prípadov vyznačujú stabilne nadpriemernou politickou reprezentáciou. Zároveň však ani jedno z krajských miest' nedosiahlo nadpriemer vo všetkých sledovaných vol'bách, dokonca ani Košice, ktoré napriek svojmu postaveniu druhého najvýznamnejšieho jadra krajiny, z hl'adiska politickej reprezentácie nevyčnievajú nad ostatnými krajskými mestami. Priemerný index reprezentácie Košíc $(4,19)$ je v porovnaní s okresom Banská Bystrica $(6,25)$, Trenčín $(5,14)$ či Trnava $(5,01)$ dokonca podstatne nižší. Výnimku zo vzorca nadpriemerne reprezentovaných okresov s krajskými 
mestami predstavuje Prešov, ktorý dosiahol nadpriemernú reprezentáciu len v jedných vol'bách (2010), pričom priemerná hodnota indexu jeho politickej reprezentácie je len 2,93. Identifikovaný západo-východný gradient politickej reprezentácie sa tak po úrovni krajov prejavuje aj na úrovni krajských miest.

Ostatné okresy so stabilne nadpriemernou reprezentáciou ležia bud' v blízkosti krajského centra a vytvárajú s ním spoločné regionálne jadro, čo môže platit' pre okresy Zvolen a Banská Štiavnica vo vzt'ahu k Banskej Bystrici alebo okres Kysucké Nové Mesto vo vzt’ahu k Žiline, alebo ide o menšie okresy, pri ktorých aj jeden poslanec NR SR (na malý počet oprávnených voličov okresu) spôsobí vysokú hodnotu indexu politickej reprezentácie. Týka sa to takých okresov ako Medzilaborce, Stropkov, Tvrdošín, Púchov, ale aj spomínaná Banská Štiavnica a Kysucké Nové Mesto. Na strane druhej máme niekol'ko malých okresov (Myjava, Bytča, Turčianske Teplice, Žarnovica, Poltár a Gelnica), z ktorých za celé sledované obdobie nebol zvolený žiaden poslanec. Možným vysvetlením tu môže byt' okrem ich vymedzenia (malého počtu obyvatel'ov) aj ich periférna poloha v rámci väčších regiónov.

\section{Geografická reprezentativita zastúpenia politických strán v NR SR}

V šiestich parlamentných vol'bách v období 1998 - 2016 bolo do NR SR zvolených 900 poslancov, ktorí sa tam dostali na kandidátnych listinách 17 rôznych politických strán a hnutí. Vysokú variabilitu straníckeho systému naznačuje aj skutočnost', že ani jedna z týchto strán nebola súčast'ou NR SR všetkých šest' sledovaných volebných období. Takmer polovica (8) z analyzovaných politických strán sa v období 1998 - 2016 dostala do NR SR len raz. Najúspešnejšia bola strana Smer-SD, ktorá v piatich vol'bách dostala do parlamentu 269 poslancov $^{8}$. Nasledujú strany SDKÚ-DS (98 poslancov), HZDS (94), KDH (60), SNS (58) až po stranu Siet' s najmenším počtom zvolených poslancov (10).

Vzorce geografickej reprezentativity jednotlivých politických strán na úrovni krajov ukazuje tabulka č. 3 a v grafickej podobe obrázok č. $4^{9}$. Dominancia politickej reprezentácie Bratislavy, resp. Bratislavského kraja je opät' jednou zo základných čŕt tohto vzorca, jej miera je však u jednotlivých strán rôzna. Absolútne najvyššia je u strany ANO $(7,55)$, kde takmer všetci poslanci (s výnimkou jedného) pochádzali z Bratislavského kraja. Vel'mi vysokú mieru politického zastúpenia Bratislavského kraja majú aj strany Sme

\footnotetext{
${ }^{8}$ Celkový počet poslancov zvolených za jednotlivé strany bol v skutočnosti nižší, ked’že niektorí poslanci boli zvolení opakovane, vid’ vysvetlenie v metodike článku.

9 Pre grafické znázornenie vzorcov regionálnej diferenciácie politického zastúpenia boli vybrané politické strany, ktoré sa dajú v súčasnosti považovat' za najviac relevantné. Vzorce ostatných strán sú pomerne dobre čitatel'né aj z tabul'ky č. 3.
} 
rodina $^{10}(5,88)$ a SaS $(5,84)$. V prípade strany Sme rodina, ktorá do volebnej sútaže vstúpila krátko pred vol'bami 2016 ako politický projekt založený na jednej osobnosti (podobne ako ANO v roku 2002), je minimálne politické zastúpenie regiónov pochopitel'né. Viac diskutabilné je to v prípade strany SaS, ktorá istý čas ašpirovala na pozíciu lídra opozície. Aj ked' ide o pravicovoliberálnu stranu, ktorej stranícka a v značnej miere aj voličská základňa je

Tabul'ka č. 3: Geografická reprezentativita parlamentného zastúpenia politických strán v rokoch 1998 - 2016

\begin{tabular}{|c|c|c|c|c|c|c|c|c|c|c|}
\hline \multicolumn{2}{|c|}{$1998-2016$} & \multicolumn{8}{|c|}{ Kraje } & \multirow[b]{2}{*}{$\begin{array}{l}\text { Roz- } \\
\text { ptyl }\end{array}$} \\
\hline Strana & $\begin{array}{c}\text { Počet } \\
\text { poslan- } \\
\text { cov }\end{array}$ & $\begin{array}{c}\text { Bratislav- } \\
\text { ský }\end{array}$ & Trnavský & $\begin{array}{l}\text { Trenčian- } \\
\text { ský }\end{array}$ & Nitrianský & Žilinský & $\begin{array}{l}\text { Bansko- } \\
\text { bystrický }\end{array}$ & $\begin{array}{l}\text { Prešov- } \\
\text { ský }\end{array}$ & $\begin{array}{l}\text { Košic- } \\
\text { ký }\end{array}$ & \\
\hline Smer-SD & 269 & 3,22 & 0,53 & 0,79 & 0,73 & 0,47 & 0,95 & 0,54 & 0,80 & 0,83 \\
\hline $\begin{array}{l}\text { SDKÚ- } \\
\text { DS }\end{array}$ & 98 & 3,38 & 0,49 & 0,82 & 0,54 & 0,65 & 0,76 & 0,73 & 0,66 & 0,94 \\
\hline HZDS & 94 & 3,44 & 0,61 & 0,95 & 0,64 & 0,76 & 0,61 & 0,46 & 0,61 & 0,98 \\
\hline KDH & 60 & 2,56 & 1,44 & 0,30 & 1,00 & 0,53 & 0,41 & 1,32 & 0,48 & 0,58 \\
\hline SNS & 58 & 2,37 & 0,50 & 1,07 & 0,39 & 2,60 & 0,57 & 0,12 & 0,49 & 0,90 \\
\hline SMK & 55 & 1,91 & 2,44 & 0,00 & 2,19 & 0,00 & 0,90 & 0,00 & 0,78 & 1,05 \\
\hline SaS & 54 & 5,84 & 1,06 & 0,33 & 0,00 & 0,29 & 0,31 & 0,27 & 0,13 & 3,88 \\
\hline SDK & 42 & 4,04 & 0,68 & 0,85 & 0,18 & 0,38 & 0,78 & 0,69 & 0,51 & 1,55 \\
\hline Most-Híd & 38 & 3,62 & 2,77 & 0,00 & 0,59 & 0,21 & 0,65 & 0,00 & 0,56 & 1,87 \\
\hline OLaNO & 35 & 2,77 & 1,64 & 0,00 & 0,00 & 1,36 & 0,24 & 1,65 & 0,41 & 1,00 \\
\hline SDL' & 23 & 2,81 & 0,42 & 0,77 & 0,98 & 1,03 & 1,07 & 0,63 & 0,31 & 0,61 \\
\hline ANO & 15 & 7,55 & 0,00 & 0,00 & 0,00 & 0,00 & 0,00 & 0,48 & 0,00 & 7,02 \\
\hline LS NS & 14 & 0,58 & 1,37 & 0,64 & 1,08 & 0,57 & $\mathbf{3 , 5 3}$ & 0,00 & 0,51 & 1,18 \\
\hline SOP & 13 & 4,35 & 0,00 & 0,68 & 0,58 & 0,00 & 1,27 & 0,00 & 1,10 & 2,09 \\
\hline KSS & 11 & 2,94 & 0,87 & 0,81 & 0,00 & 0,72 & 0,75 & 1,31 & 0,65 & 0,74 \\
\hline $\begin{array}{l}\text { Sme } \\
\text { rodina }\end{array}$ & 11 & 5,88 & 0,00 & 0,00 & 1,37 & 0,00 & 0,00 & 0,65 & 0,00 & 4,15 \\
\hline Siet' & 10 & 2,43 & 0,96 & 1,78 & 0,00 & 1,59 & 0,00 & 0,00 & 1,43 & 0,88 \\
\hline Priemer & & 3,33 & 0,88 & 0,64 & 0,67 & 0,65 & 0,75 & 0,54 & 0,61 & 0,89 \\
\hline
\end{tabular}

Zdroj: NR SR, vlastné prepočty 10 Oficiálny názov strany je Sme rodina - Boris Kollár. Z pragmatických dôvodov je v tabul'ke č. 3 a následne aj v texte
používaný zjednodušený názov Sme rodina. To isté platí aj pre stranu Kotleba - L'S NS. 
vel’mi silno koncentrovaná práve v Bratislave, nedostatočné stranícke zázemie $\mathrm{v}$ regiónoch môže byt' $\mathrm{z}$ hl'adiska vyšších politických ašpirácií tejto strany kontraproduktívne. To sa ukazuje napríklad v regionálnych a komunálnych vol'bách, v ktorých strana $\mathrm{SaS}$ zaznamenáva podstatne nižšie zisky nielen v porovnaní so svojimi výsledkami v parlamentných vol'bách, ale aj v porovnaní s ostatnými politickými stranami.

Jedinou politickou stranou, pri ktorej bola politická reprezentácia Bratislavského kraja podpriemerná $(0,58)$, bola L'S NS. Pri tejto strane výraznejšie dominovala reprezentácia Banskobystrického kraja (3,53), za ktorým nasledovali kraje Trnavský a Nitriansky. Tento vzorec vychádza z rozmiestnenia straníckeho, ako aj voličského jadra tejto strany. Ďalšími prípadmi, kedy Bratislavský kraj síce dosahoval nadpriemerné politické zastúpenie, avšak jadro politickej reprezentácie ležalo v iných krajoch, sú strany SMK a SNS. V prípade SNS má najsilnejšie postavenie Žilinský kraj $(2,6)$. U SMK sa voličská aj členská základňa strany nachádza v regiónoch južného Slovenska, čomu zodpovedá aj vzorec geografickej reprezentácie, v ktorom dominujú Nitriansky $(2,45)$ a Trnavský kraj $(2,15)$. Zaujímavé je z tohto pohladu porovnanie SMK so stranou Most-Híd, ktorej kandidátka a zároveň aj voličská základňa reflektovali občiansky (slovensko-mad'arský) koncept, čo sa prejavilo aj na vzorci geografickej reprezentácie, v ktorom už dominovala Bratislava $(3,62)$ a z južných regiónov dosiahol nadpriemernú hodnotu len Trnavský kraj $(2,77)$. Silnejšie zakotvenie členskej základne SMK v regiónoch sa prejavuje aj v komunálnych a regionálnych vol'bách, $\mathrm{v}$ ktorých dosahuje lepšie výsledky v porovnaní s Mostom-Híd.

Vzt'ah medzi vzorcom geografickej reprezentativity a vzorcom volebnej podpory v regiónoch nachádzame popri už spomínaných stranách SaS, L'S NS, SNS, SMK a Most-Híd aj pri KDH a OLaNO. Ak sa pri týchto politických subjektoch pozrieme na regióny mimo Bratislavy, uvidíme nadpriemernú reprezentáciu Trnavského a Prešovského kraja pri KDH a Trnavského, Žilinského a Prešovského kraja pri OLaNO. Práve v týchto regiónoch je možné v rámci Slovenska hladat' pravicovo-konzervatívne prostredie, ktoré stojí vo vel’mi významnej (KDH), resp. významnej (OLaNO) miere za voličskou podporou týchto politických subjektov. KDH sa podobne ako SMK vyznačuje dobre vybudovanou a silnou členskou základňou $\mathrm{v}$ regiónoch, $\mathrm{z}$ ktorej vedia tieto $\mathrm{v}$ súčasnosti mimoparlamentné strany ponúknut' úspešných kandidátov pre regionálne a komunálne vol'by. V nich bolo $\mathrm{KDH}$ v posledných rokoch vzhl'adom na počet regionálnych a komunálnych poslancov druhým najúspešnejším politickým subjektom po Smere-SD. Príčiny zvýšenej politickej reprezentácie regiónov, ako aj úspechu jej kandidátov napr. v posledných regionálnych vol'bách (2017), treba v prípade hnutia OL'aNO (na rozdiel od KDH a SMK) hl'adat' inde ako v silnej členskej základni v regiónoch, ked’že tento politický

Sociológia 51, 2019, č. 5 
Obrázok č. 4: Vzorce geografickej reprezentativity parlamentného zastúpenia vybraných politických strán $(1998$ - 2016)
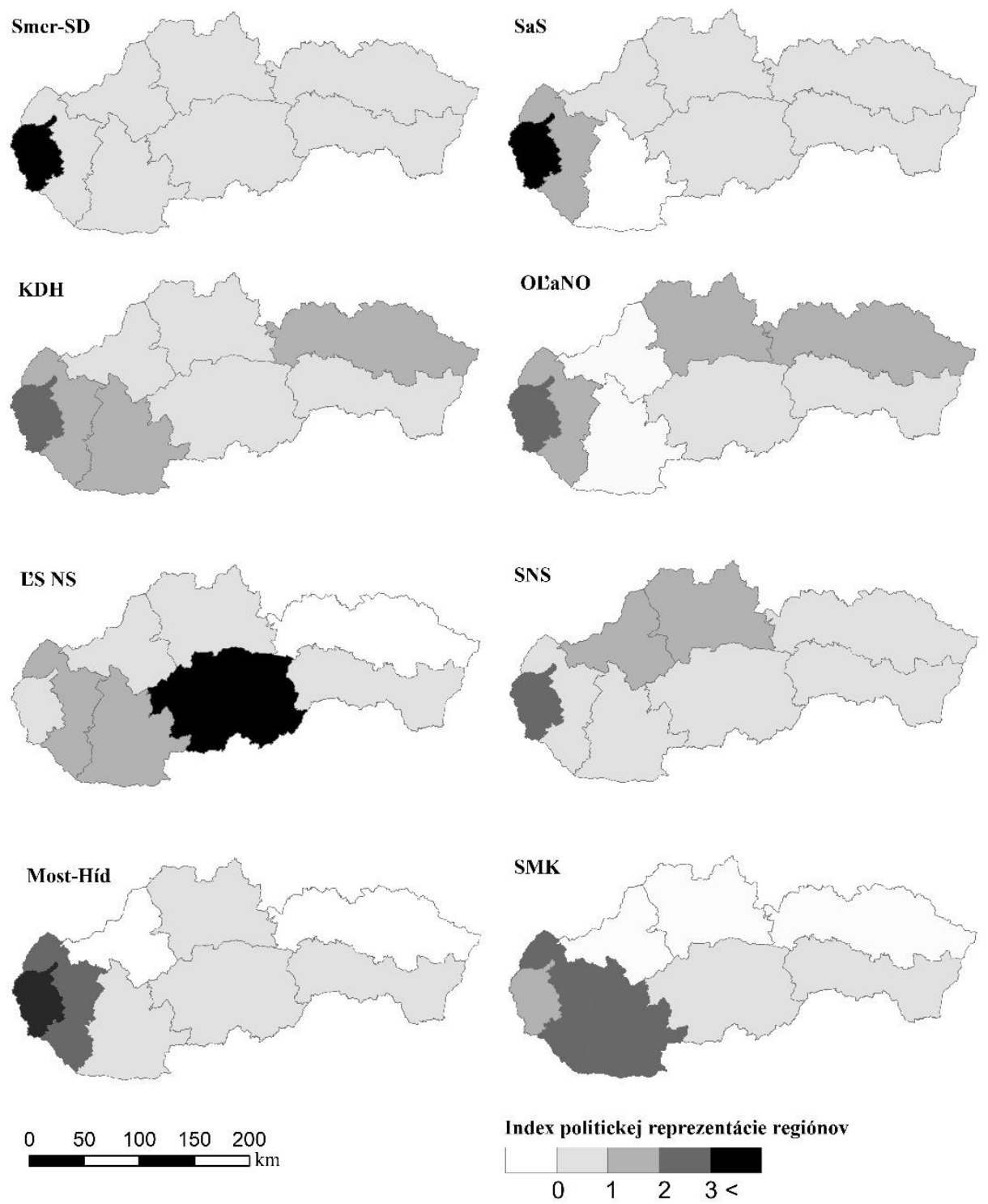

Zdroj: NR SR, spracoval autor

subjekt nemá dostatočne vybudovanú ani centrálnu stranícku štruktúru. Koncept OLaNO je postavený na osobnostiach, ktoré dokážu byt' úspešné v regiónoch, z ktorých pochádzajú (ako napr. J. Viskupič v Trnave alebo E. Jurinová 
na Orave). Volebnú stratégiu postavenú na osobnostiach z regiónov (napr. I. Janckulík z Oravy, A. Hrnčiar z Martina alebo K. Macháčková z Prievidze) zvolila aj strana Siet', čo sa odrazilo nielen vo vzorci jej regionálnej reprezentácie, ale aj v regionálnom rozmiestnení volebnej podpory tejto strany.

Stranami, pri ktorých je možné, na rozdiel od vyššie spomínaných strán, nájst' výrazný nesúlad medzi vzorcom geografickej reprezentácie a vzorcom volebnej podpory v regiónoch, sú HZDS a Smer-SD. Pri oboch stranách dominuje politické zastúpenie Bratislavy, hoci volebná podpora týchto subjektov bola v hlavnom meste stabilne nízka. Na strane druhej nedosahuje hodnota politického zastúpenia $\mathrm{v}$ žiadnom $\mathrm{z}$ ostatných regiónov nadpriemernú hodnotu, a to ani v regiónoch, ktoré predstavujú ich najdôležitejšie voličské jadrá (regióny severozápadného, resp. severovýchodného Slovenska). Vo vzorci geografickej reprezentácie Smeru-SD majú dokonca Žilinský a Prešovský kraj najnižšie zastúpenie $(0,47$, resp. 0,54$)$. Tento nesúlad je ešte výraznejší v kontexte snahy týchto dvoch subjektov vymedzovat' sa voči hlavnému mestu a klást' dôraz na regióny. Vysvetlenie je možné hl'adat' v pozícii týchto politických subjektov ako strán moci, ktorá sa má tendenciu koncentrovat' práve v hlavnom meste. Vel'a politikov týchto strán sa časom kvôli výkonu vysokých štátnych funkcií prest’ahovalo do hlavného mesta. Tieto skutočnosti však voliči týchto strán pravdepodobne až tak nereflektujú, pretože ich voličská podpora je naviazaná predovšetkým na osobu lídra strany.

Podobný vzorec geografickej reprezentácie ako u HZDS a Smeru-SD nachádzame aj pri stranách SDKÚ-DS a SDK, ktoré by sa tiež dali považovat' za strany nesúce dôležitý podiel na moci, a teda spojené s hlavným mestom, avšak na rozdiel od HZDS a Smeru-SD sa voči hlavnému mestu nevymedzovali a voličská podpora v Bratislave bola pre tieto strany vel'mi významná.

Zaujímavým údajom o identifikovaných vzorcoch geografickej reprezentácie pri jednotlivých stranách je aj hodnota rozptylu, resp. variability ich zastúpenia v regiónoch (tab. č. 3). Najvyšší rozptyl, teda najvyššie rozdiely v miere politickej reprezentácie a zároveň najvyššia regionálna koncentrácia politického zastúpenia existuje pri stranách ANO, Sme rodina a SaS. Na opačnej strane sú KDH a SDL', ktorých vzorec má najnižší rozptyl, čo znamená najrovnomernejšie rozmiestnenie politickej reprezentácie v regiónoch. Ide o politické subjekty, ktoré majú, resp. mali (SDL) vel'mi dobre vybudované stranícke štruktúry $\mathrm{v}$ regiónoch ${ }^{11}$, čo sa ukazuje napríklad pri výsledkoch komunálnych a regionálnych volieb, v ktorých dokážu ponúknut' dostatok $\mathrm{v}$ regiónoch známych a zvolitel'ných kandidátov ${ }^{12}$.

\footnotetext{
${ }^{11} \mathrm{~V}$ prípade SDL' prevzala tieto dobre vybudované regionálne stranícke štruktúry strana Smer-SD.

12 KDH malo v komunálnych vol'bách z politických strán po Smere-SD druhý najvyšší počet zvolených starostov a poslancov napriek tomu, že $\mathrm{v}$ súčasnosti ide o mimoparlamentnú stranu.
} 


\section{Diskusia a závery}

Identifikované vzorce geografickej reprezentativity ukazujú výraznú dominanciu politického zastúpenia regiónu hlavného mesta, ktorý je možné považovat' za najdôležitejšie ekonomické a politické jadro celej krajiny. Pre zvyšok krajiny platí tzv. západo-východný gradient, kedy miera politickej reprezentácie regiónov od západu smerom na východ klesá. Po Bratislave je druhým priemerne najviac reprezentovaným regiónom Trnavský kraj, ktorý je možné považovat' za širšie zázemie Bratislavy, zatial' čo najmenej reprezentovanými sú regióny východného Slovenska. Vo vzorci politickej reprezentácie sa tak vôbec neodráža pozícia sekundárneho jadra štátu - Košíc, a to nielen na úrovni kraja, ale ani na úrovni samotného mesta, kde sú Košice dokonca menej politicky reprezentované aj v porovnaní s d’alšími krajskými mestami ako Trnava, Trenčín či Banská Bystrica. Vzorec politickej reprezentácie regiónov sa tak približuje vzorcu socioekonomickej diferenciácie regiónov Slovenska, kde existuje dichotomické členenie (obr. č. 3) na nadpriemerne rozvinutý severozápad a zaostávajúci juhovýchod krajiny (vid' napr. Korec 2005, Halás 2014). Periférny status regiónov sa tak na Slovensku prejavuje nielen $\mathrm{v}$ socioekonomickej rovine, ale aj v rovine politickej, a to vel'mi stabilne a výrazne. Zatial' čo socioekonomické aspekty regionálnych rozdielov sú na Slovensku zo strany sociológov, ekonómov či geografov pomerne dobre preskúmané, výskumu politickej marginality regiónov, ktorá sa okrem vzorcov politickej reprezentácie regiónov prejavuje napr. aj v regionálnej diferenciácii volebnej účasti, nie je venovaná výraznejšia pozornost'.

Pre komparáciu identifikovaných vzorcov politickej reprezentácie regiónov na Slovensku sú zaujímavé predovšetkým dve práce, ktoré analyzujú geografickú reprezentativitu $v$ rámci pomerného volebného systému. Latner a McGann (2005) analyzovali vzorce geografickej reprezentácie v prípade Holandska a Izraela, ktoré majú podobne ako Slovensko len jeden volebný obvod. Pohl'ad na politickú reprezentáciu regiónov v prípade existencie viacerých volebných obvodov podáva na príklade Českej republiky štúdia Mikešovej a Kosteleckého (2016).

Latner a McGann (2005) zistili, že v podmienkach jedného volebného obvodu majú väčšie zastúpenie jednak poslanci pochádzajúci z jadrových regiónov, ale aj z regiónov periférnych, ak sa vyznačujú nejakou špecifickou identitou $^{13}$. V komparácii so závermi Latnera a McGanna (2005) je dominancia politickej reprezentácie regiónu hlavného mesta na Slovensku ovel’a výraznejšia. V priemere je pätnásobne vyššia než relatívne vyrovnaná reprezentácia ostatných siedmych krajov. V prípade Holandska a Izraela je možné menej

13 Ako napríklad Západný breh Jordánu v prípade Izraela. 
výraznú politickú dominanciu jadier štátu vysvetlit’ jednak existenciou viacerých jadrových regiónov ${ }^{14}$ a jednak nadpriemernou reprezentáciou špecifických periférnych regiónov, čo v prípade Slovenska neplatí. Za periférne regióny so špecifickou identitou je na Slovensku možné považovat' predovšetkým južné regióny obývané mad'arskou menšinou ${ }^{15}$. Vysvetlenie tohto zistenia je možné hl'adat' v dvoch rovinách. Prvá súvisí s počtom mandátov politickej strany reprezentujúcej mad'arskú menšinu. V rokoch 1998 až 2006, kedy sa do parlamentu dostávala SMK, bola reprezentácia okresov južného Slovenska na vyššej úrovni ako v druhej polovici skúmaného obdobia (2010 - 2016), kedy čast' mad’arských voličov voliacich mimoparlamentnú SMK reprezentovaná nebola, a v prípade strany Most-Híd platilo, že získavala nielen menší podiel hlasov, ale aj to, že čast' poslancov tejto strany geograficky reprezentovala aj slovenské prostredie, predovšetkým Bratislavu. Druhé vysvetlenie je možné hl'adat' vo vymedzení okresov na južnom Slovensku, ktoré patria medzi najväčšie na Slovensku, a s výnimkou okresov Dunajská Streda a Komárno nepredstavujú čisto mad'arské prostredie. Ak by sme teda v zmysle zistení Latnera a McGanna (2005) hl'adali vzorec reprezentácie regiónov so špecifickou (menšinovou) identitou, administratívne vymedzenie regiónov (krajov aj okresov) naše zistenia $\mathrm{v}$ tomto smere čiastočne skresluje.

Pre geografické práce je vo všeobecnosti vel'mi dôležité vymedzenie regiónov, ktoré tvoria základný priestorový rámec analýzy. Vymedzenie existujúcich krajov ani okresov na Slovensku nie je z geografického hladiska ideálne. V prípade krajov sú na strane jednej viaceré prirodzené regióny ako Záhorie, Spiš alebo Gemer rozdelené medzi viacero krajov, na strane druhej sa z hl'adiska volebnej geografie nachádzajú v rámci jedného kraja viaceré prirodzené regióny s často vel'mi odlišnými politickými preferenciami ${ }^{16}$. Pri vymedzení okresov je problémom predovšetkým absencia princípu priestorovej spravodlivosti, to znamená extrémne disproporcie vo vel'kosti a počte obyvatel'ov súčasných okresov ${ }^{17}$.

Vychádzajúc z podobného historického, ekonomického a politického kontextu je zaujímavé porovnat' vzorec politickej reprezentácie regiónov na Slovensku s Českou republikou, kde pri vol'bách do dolnej komory parlamentu existuje taktiež pomerný volebný systém, avšak krajina je rozdelená na 14

\footnotetext{
14 Provincie Noord-Holland a Zuid Holland v Holandsku, resp. Jeruzalem a Tel Aviv v Izraeli.

15 Výnimku v tomto periférnom statuse predstavuje len okres Dunajská Streda, ktorý je možné považovat’ za zázemie Bratislavy.

${ }^{16}$ Pri analýze identifikovaných vzorcov na úrovni krajov je preto potrebné brat' do úvahy, z ktorých prirodzených regiónov kraj pozostáva. Ked’ sme napríklad identifikovali nadpriemernú politickú reprezentáciu strán KDH a OLaNO v Žilinskom kraji a hl'adali súvislost's konzervatívnym politickým prostredím, mysleli sme predovšetkým na regióny Oravy a dolného Liptova (nie Kysuce alebo Žilinu).

17 Tento problém bol síce riešený v rámci metodiky prácou s relatívnymi číslami, avšak pri vel'mi malých okresoch mohol výskyt politického zastúpenia vo forme jedného poslanca (v niektorých vol'bách) znamenat' vel'mi dobré celkové umiestnenie tohto okresu (napr. Medzilaborce alebo Kysucké Nové Mesto).
} 
volebných obvodov zodpovedajúcich existujúcim krajom. Mikešová a Kostelecký (2016), vychádzajúc tiež z metodiky Latnera a McGanna (2005), zistili v podmienkach existencie viacerých volebných obvodov postupnú stratu politickej dominancie centra (Prahy) a posilňovanie zastúpenia poslancov $\mathrm{z}$ regiónov a regionálnych centier. To podl'a nich prispelo k postupnej decentralizácii a regionalizácii politickej moci $\mathrm{v}$ Česku, čo je v kontraste s pretrvávajúcou ekonomickou dominanciou Prahy.

Výrazná dominancia regiónu hlavného mesta sa prejavuje aj vo vzorcoch geografickej reprezentativity väčšiny politických strán na Slovensku. Jedným z vysvetlení môže byt', že politici, ktorí sa dostanú do vedenia politických strán, resp. do vysokých štátnych funkcií, sa z praktických dôvodov časom prest’ahujú do hlavného mesta. To platí predovšetkým pre strany, ktoré dlhé roky dominovali stranícko-politickému systému na Slovensku. Vo vzorci geografickej reprezentativity strán HZDS a Smer-SD dominoval región Bratislavy napriek tomu, že sa voči nemu často politicky vymedzovali a voličskú podporu získavali v iných regiónoch Slovenska, z ktorých však žiaden nedosahuje ani priemernú úroveň ich politickej reprezentácie. Týmto stranám pravdepodobne stačilo, že ich líder, na ktorého bola naviazaná voličská podpora, mohol vd’aka jednému volebnému obvodu kandidovat' vo všetkých regiónoch Slovenska.

Ďalším zaujímavým zistením je, že v prípade väčšiny ostatných politických strán sa vzorec geografickej reprezentativity mimo Bratislavy približuje vzorcom ich volebnej podpory v regiónoch. Môže to súvisiet' so stratégiou jednotlivých politických strán pri zostavovaní kandidátnej listiny ${ }^{18}$, ale môže to naznačovat' aj existenciu vzt’ahu medzi voličskou základňou a kandidátmi v jednotlivých regiónoch, ktorý je vo volebnej geografii známy ako tzv. susedský efekt (napr. Gimpel et al. 2008, Johnston et al. 2016). Skrýva sa za ním tendencia uprednostnit' kandidátov, ktorí sú voličom geograficky blízki. Voliči od takýchto kandidátov očakávajú, že budú lepšie chápat potreby regiónu, z ktorého pochádzajú. Tento fenomén je možné v podmienkach volebného systému na Slovensku skúmat' prostredníctvom tzv. preferenčných hlasov, ktorými môžu voliči čiastočne ovplyvnit’ poradie na celoštátnych kandidátnych listinách (Spáč 2013, v prípade Česka napr. Malcová 2012, Voda - Pink 2009).

Vychádzajúc z analytického a komparatívneho rámca tejto štúdie je Slovensko zaujímavým príkladom toho, ako systém jedného volebného obvodu pre celú krajinu vedie $\mathrm{k}$ vysokej centralizácii politickej moci nielen v geografickom zmysle, ale aj v kontexte fungovania stranícko-politického systému. Väčšine tých politických strán, ktorých volebná podpora je založená na popularite jednej osobnosti, systém jedného volebného obvodu viac-menej vyhovuje.

\footnotetext{
${ }^{18}$ V tomto smere by mohla byt' zaujímavá podrobnejšia analýza toho, či a ako politické strany reflektujú pri zostavovaní kandidátnych listín výsledky predchádzajúcich volieb v jednotlivých regiónoch.
} 
Vd’aka nemu môže stranícky líder, prípadne niekol'ko d’alších známych osôb z jeho okolia, resp. vedenia strany, kandidovat' naprieč celou krajinou od Skalice až po Sninu. Na strane druhej môže niektorým politickým stranám vyhovovat' systém, ktorý ich nenúti budovat' silnejšie regionálne stranícke štruktúry, ktoré by teoreticky mohli oslabovat' moc straníckych centrál. Zvolení poslanci sa $\mathrm{v}$ takto nastavenom systéme cítia ovel'a viac zaviazaní vedeniu strany, ktoré ich na celoštátnej kandidátnej listine umiestnilo na zvolitel'né miesto, než svojim voličom, ktorí sú v systéme jedného volebného obvodu ovel'a anonymnejší a t’ažšie identifikovatel'nejší. Hoci zvolení poslanci oficiálne reprezentujú všetkých občanov krajiny, reálne často reprezentujú predovšetkým politickú stranu, za ktorú boli zvolení. Vzt’ah medzi poslancom a centrálou politickej strany je tak ovel'a silnejší ako vzt’ah medzi poslancom a jeho voličom. To môže viest' $\mathrm{k}$ situácii, že volič nevie, kto ho politicky zastupuje, resp. môže mat' pocit, že politika je od neho vel'mi vzdialená.

$\mathrm{V}$ rámci prebiehajúcej diskusie o efektívnom nastavení volebného systému pre parlamentné vol'by na Slovensku existuje viacero návrhov, ktoré idú od kozmetických úprav až po zásadnú zmenu systému, napríklad z pomerného na väčšinový. Každá zmena volebného systému by mala byt' odbornou verejnost’ou dôkladne prediskutovaná a prijatá širokým politickým konsenzom. V kontexte diskusie o rovnomernejšom politickom zastúpení jednotlivých regiónov sa ako jedno z riešení ponúka zavedenie viacerých volebných obvodov pri zachovaní súčasného pomerného volebného systému ${ }^{19}$, čo by mohlo prispiet' aj k väčšej decentralizácii politickej moci na Slovensku. Politické strany by tak museli lepšie rozvíjat' svoje regionálne stranícke štruktúry, a v politických programoch a stratégiách viac zohl'adňovat' špecifické potreby a záujmy jednotlivých regiónov. Systém viacerých volebných obvodov by mohol čiastočne eliminovat' pre Slovensko typický fenomén podpory politických strán založenej na popularite jedného človeka. Potreba hl'adat' a nominovat' na kandidátne listiny osobnosti z regiónov by mohla pomôct' vytvorit' lepšie podmienky pre bližší vzt’ah medzi občanom a jeho politickým reprezentantom, a prispiet' tak k vyššej občianskej participácii a rozvoju občianskej spoločnosti.

Tibor Madleňák pôsobí na Katedre geografie a geológie Fakulty prírodných vied Univerzity Mateja Bela v Banskej Bystrici. Venuje sa výskumu geografických aspektov volieb a volebného správania.

\footnotetext{
19 Napríklad po vzore Českej republiky v hraniciach existujúcich krajov, ktorým by bol proporčne (vzhl’adom na počet obyvatel'ov alebo voličov) pridelený istý počet poslancov v NR SR.
} 


\section{LITERATÚRA}

AGNEW, J., 2016: Place and Politics: The Geographical Mediation of State and Society. London: Routledge, $286 \mathrm{~s}$.

BERNARD, J. - KOSTELECKÝ, T., 2014: Prostorový kontext volebního chování jak působí lokální a regionální prostředí na rozhodování voličů. Sociologický časopis 50, č. 1, s. 3-28.

FLINT, C. - TAYLOR, P., 2007: Political Geography. Harlow: Pearson, 355 s.

GIMPEL, J. - KARNES, K. - MCTAGUE, J. - PEARSON-MERKOWITZ, S., 2008: Distance-Decay in the Political Geography of Friends-and-Neighbors Voting. Political Geography 27, č. 2, s. 231-252.

GIMPEL, J. - LEE, F. - THORPE, R., 2011: The Wellspring of Political Candidate Emergence: Geographic Origins of Statewide Candidates in the United States. Political Geography 30, č. 1, s. 25-37.

HALÁS, M., 2014: Modelovanie priestorového usporiadania a dichotómie centrum periféria. Geografie 119, č. 4, s. 384-405.

JOHNSTON, R. - WICKHAM-JONES, M. - PATTIE, Ch. - CUTTS, D. PEMBERTON, H., 2016: Friends and Neighbours Voting Revisited: The Geography of Support for Candidates to Lead the UK's Labour Party. Political Geography 55, č. 1, s. 1-9.

KEREKEŠ, D. - PINK, M. - ŠEDO, J., 2019: Slovenské stranické zemětřesení 2016. Pomohla by malá volební reforma? Sociológia 51, č. 1, s. 64-83.

KOREC, P., 2005: Regionálny rozvoj Slovenska v rokoch 1989 - 2004. Bratislava: Geografika, $227 \mathrm{~s}$.

KRIVÝ, V. - FEGLOVÁ, V. - BALKO, D., 1996: Slovensko a jeho regióny. Sociokultúrne súvislosti volebného správania. Bratislava: Nadácia Média, $414 \mathrm{~s}$.

LATNER, M. - McGANN, A., 2005: Geographical Representation under Proportional Representation: The Cases of Israel and the Netherlands. Electoral Studies 24, č. 4, s. 709-734.

LEE, F., 2007: Geographic Representation and the U.S. Congress. Maryland Law Review 67, č. 1, s. 51-61.

MADLEŇÁK, T., 2010: Hlavné trendy výskumu v súčasnej volebnej geografii. Geografický časopis 62, č. 2, s. 127-145.

MADLEŇÁK, T., 2012: Regionálna diferenciácia volebného správania na Slovensku (1998 - 2010). Bratislava: VEDA, 232 s.

MADLEŇÁK, T., 2017: Potenciálna a reálna reprezentácia regiónov Slovenska. Geographia Cassoviensis 11, č. 2, s. 153-166.

MALCOVÁ, K., 2012: Lokální aspekt volební podpory kandidátů do Senátu Parlamentu ČR. Sociologický časopis 48, č. 2, s. 283-313.

MIKEŠOVÁ, R. - KOSTELECKÝ, T., 2016: Geografická reprezentativita poslanců zvolených do Poslanecké sněmovny českého parlamentu za první republiky a po roce 1989. Středoevropské politické studie 18, č. 4, s. 354-380.

NOVÁK, M., 1997: Is There One Best Model of Democracy? Efficiency and Representativeness: Theoretical Revolution or Democratic Dilemma? Czech Sociological Review 5, č. 2, s. 1-33. 
NR SR - Národná rada Slovenskej republiky: https://www.nrsr.sk/web/ Default.aspx?sid=poslanci/zoznam_abc\&ListType=0\&CisObdobia=7.

PITKIN, H. F., 1972: The Concept of Representation. Berkeley: University of California Press, $330 \mathrm{~s}$.

SPÁČ, P., 2013: Tichý hlas voličov: preferenčné hlasovanie v slovenských parlamentných vol'bách. Brno: Centrum pro studium demokracie a kultury, $234 \mathrm{~s}$.

SPÁČ, P. - SLOBODA, D., 2014: Municipalizácia, volebný systém a možnosti participácie v miestnej samospráve na Slovensku. Piešt’any: Komunálne výskumné a poradenské centrum, $68 \mathrm{~s}$.

STRMISKA, M. - HLOUŠEK, V. - KOPEČEK, L. - CHYTILEK, R., 2005: Politické strany moderní Evropy. Praha: Portál, $728 \mathrm{~s}$.

VODA, P. - PINK, M., 2009: Kandidáti v poslaneckých volbách. Analýza preferenčního hlasování ve volbách do PS PČR v roce 2006. Středoevropské politické studie 11, č. 2- 3, s. 163-180.

ZEMKO, M., 2008: Volebný zákon do Poslaneckej snemovne Národného zhromaždenia za prvej Československej republiky a strany národnostných menšín. Historický časopis 56, č. 1, s. 81-92. 